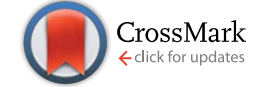

Cite this: RSC Adv., 2017, 7, 1943

Accepted 30th November 2016

DOI: $10.1039 / c 6 r a 26319 d$

www.rsc.org/advances

\section{Two pairs of enantiomeric $\alpha$-pyrone dimers from the endophytic fungus Phoma sp. YN02-P-3†}

\author{
Xia-Nan Sang, ${ }^{\text {ab }}$ Shao-Fei Chen, ${ }^{\text {ab }}$ Gang Chen, ${ }^{\text {ab }}$ Xiao An, ${ }^{\text {ab }}$ Sheng-Ge Li, ${ }^{\text {ab }}$ \\ Xiao-Jie Lu, ${ }^{a b}$ Dan Zhao, ${ }^{\text {ab }}$ Jiao Bai, ${ }^{a b}$ Hai-Feng Wang ${ }^{* a b}$ and Yue-Hu Pei*ab
}

$( \pm)$ Phomones A (1) and B (2), two pairs of novel enantiomeric $\alpha$-pyrone dimers from the endophytic fungus Phoma sp. YN02-P-3 are reported. Compounds 1 and 2 are the first examples of 6 - $\alpha, \beta$-unsaturated ester2 -pyrone dimers, and compound 1 possesses a novel 6/4/5/6 tetracyclic ring system. Their structures and stereochemistry were determined by the analysis of extensive spectroscopic data, ECD calculations and single-crystal X-ray diffraction data.
$[2+2]$ Cycloaddition reactions that construct two new C-C bonds and establish up to four new stereogenic centers in a single step $^{1-3}$ are widely used in the synthesis of natural ${ }^{4,5}$ and bioactive products and have been utilized to synthesize many kinds of important compounds. ${ }^{6}$ The course of the addition reaction and the resulting regioselectivities have remained a topic of great interest in this area. ${ }^{7,8} \alpha$-Pyrone is a simple heterocyclic dienone system, ${ }^{9}$ which is frequently used as the substrate of intramolecular photochemical reactions, in order to investigate the intermolecular cycloaddition reactivity. ${ }^{10-12}$

During our continuing search for novel bioactive secondary metabolites from endophytic fungi, Phoma sp. was obtained from the sample collected in the plant Sumbaviopsis J. J. Smith from Yunnan Province, China. Previous study of this fungus resulted in the isolation of six novel compounds phomeketale $\mathrm{A}-\mathrm{F},{ }^{13}$ one novel 3,4-dihydronaphthalen-1(2H)-one with spirobutyrolactone and a new isocoumarin. ${ }^{14}$ Further investigation led to the discovery of two pairs of novel enantiomeric $\alpha$-pyrone dimers, $( \pm)$ phomones A (1) and B (2), and a known compound rosellsin $(3) .{ }^{15}$ Phomones A and B are the first examples of $6-\alpha, \beta-$ unsaturated ester-2-pyrone dimers via intermolecular unsymmetrical $[2+2]$ cycloaddition. ${ }^{16,17}$ Their structures and stereochemistry were elucidated on the basis of the spectral data, single-crystal X-ray diffraction, and ECD analysis. Interestingly, it was found that phomone B (2) slowly transformed to phomone A (1) in $\mathrm{MeOH}$ over one month. The effect of $\mathrm{H}_{2} \mathrm{O}$, $\mathrm{pH}^{-}$and temperature-dependent transformation between

${ }^{a}$ Key Laboratory of Structure-Based Drug Design \& Discovery, Ministry of Education, Shenyang Pharmaceutical University, Shenyang 110016, China. E-mail: wanghaifeng0310@163.com; peiyueh@vip.163.com

${ }^{b}$ School of Traditional Chinese Materia Medica, Shenyang Pharmaceutical University, China

$\dagger$ Electronic supplementary information (ESI) available: 1D and 2D NMR, HRESIMS, UV, IR, and ECD spectra of phomones and detailed experimental procedures. CCDC 1504985. For ESI and crystallographic data in CIF or other electronic format see DOI: 10.1039/c6ra26319d compounds $\mathbf{1}$ and $\mathbf{2}$, as well as the structural elucidation, postulated biogenetic origin and biological evaluation of these metabolites are reported herein.

$( \pm)$-Phomone A (1a/1) $)$ was initially obtained as colorless block crystals. Its molecular formula was established to be $\mathrm{C}_{24} \mathrm{H}_{28} \mathrm{O}_{14}$ (eleven degrees of unsaturation) on the basis of HRESIMS at $m / z 563.1352[\mathrm{M}+\mathrm{Na}]^{+}$(calcd 563.1371). Inspection of ${ }^{1} \mathrm{H}$ and ${ }^{13} \mathrm{C}$ NMR spectra (Table 1 ) indicated one 4-oxy- $\alpha$ pyrone ring $\left(\delta_{\mathrm{C}} 163.3,110.0,168.1,116.3\right.$ and 156.3), one 4-oxy$\alpha$-dihydropyrone ring $\left(\delta_{\mathrm{C}} 163.2,107.4,164.9,53.1\right.$ and 82.6), four methoxyl groups $\left(\delta_{\mathrm{H}} 3.54, \delta_{\mathrm{C}} 57.9 ; \delta_{\mathrm{H}} 3.65, \delta_{\mathrm{C}} 51.6 ; \delta_{\mathrm{H}} 4.03\right.$, $\delta_{\mathrm{C}} 62.1$ and $\left.\delta_{\mathrm{H}} 3.78, \delta_{\mathrm{C}} 51.7\right)$, five methylene groups $\left(\delta_{\mathrm{H}} 4.28, \delta_{\mathrm{C}}\right.$ $52.5 ; \delta_{\mathrm{H}} 4.12 / 4.29, \delta_{\mathrm{C}} 74.4 ; \delta_{\mathrm{H}} 4.35, \delta_{\mathrm{C}} 52.8 ; \delta_{\mathrm{H}} 2.53 / 2.85, \delta_{\mathrm{C}} 33.9$ and $\left.\delta_{\mathrm{H}} 4.43 / 4.33, \delta_{\mathrm{C}} 52.2\right)$, three methine groups $\left(\delta_{\mathrm{H}} 4.62, \delta_{\mathrm{C}}\right.$ $79.8 ; \delta_{\mathrm{H}} 4.26, \delta_{\mathrm{C}} 40.8$ and $\left.\delta_{\mathrm{H}} 3.92, \delta_{\mathrm{C}} 47.2\right)$ and two ester carbonyls ( $\delta_{\mathrm{C}} 170.5$ and $\left.\delta_{\mathrm{C}} 169.2\right)$. The HMBC spectrum (Fig. 2) corroborated the presence of the 4-oxy- $\alpha$-pyrone ring moiety based on correlations from methylene $\mathrm{H}_{2}-10^{\prime}\left(\delta_{\mathrm{H}} 4.35\right)$ to $\mathrm{C}-2^{\prime}$ $\left(\delta_{\mathrm{C}} 163.3\right), \mathrm{C}-3^{\prime}\left(\delta_{\mathrm{C}} 110.0\right)$ and C-4 ${ }^{\prime}\left(\delta_{\mathrm{C}} 168.1\right)$ and from $\mathrm{H}_{2}-12^{\prime}\left(\delta_{\mathrm{H}}\right.$ 4.43/4.33) to C-4 $4^{\prime}, \mathrm{C}-5^{\prime}\left(\delta_{\mathrm{C}} 116.3\right)$ and C- $6^{\prime}\left(\delta_{\mathrm{C}} 156.3\right)$, and due to the other HMBC correlations, the gross structure of 1 could not be established unambiguously. Fortunately, a crystal suitable for X-ray crystallographic study (CCDC 1504985) was obtained upon slow evaporation of $\mathrm{MeOH}$ by keeping the sample at room temperature for one month. The final refinement on the $\mathrm{Cu} \mathrm{K} \alpha$ data resulted the crystal of $\mathbf{1}$ had a $p 2_{1} / c$ space group, indicating a racemic nature, which was in accordance with the lack of optical activity. Furthermore, the X-ray diffraction analysis (Fig. 3) allowed to unambiguously assign the absolute configurations of the two enantiomers of 1 to be $\left(5 R, 6 R, 7 R, 7^{\prime} S, 8^{\prime} S\right)$ and $\left(5 S^{*}, 6 S^{*}, 7 S^{*}, 7^{\prime} R^{*}, 8^{\prime} R^{*}\right)$ as Fig. 1, respectively. Separation by using chiral-phase HPLC yielded $1 \mathrm{a}\left([\alpha]_{\mathrm{D}}^{20}+30\left(\begin{array}{ccc}c & 0.20 \mathrm{MeOH}))\end{array}\right.\right.$

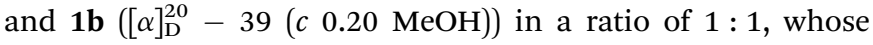
absolute configurations were established by comparing the calculated ECD spectra with the experimental spectra (Fig. 4). From the above evidence, the absolute stereochemistry for 
Table $1{ }^{1} \mathrm{H}$ and ${ }^{13} \mathrm{C}$ NMR data of 1 and $2^{a}$

\begin{tabular}{|c|c|c|c|c|}
\hline \multirow[b]{2}{*}{ Position } & \multicolumn{2}{|l|}{1} & \multicolumn{2}{|l|}{2} \\
\hline & $\delta_{\mathrm{C}}$ & $\begin{array}{l}\delta_{\mathrm{H}} \\
(\mathrm{m}, J \text { in } \mathrm{Hz})\end{array}$ & $\delta_{\mathrm{C}}$ & $\begin{array}{l}\delta_{\mathrm{H}} \\
(\mathrm{m}, J \text { in } \mathrm{Hz})\end{array}$ \\
\hline 2 & 163.2 & & 166.5 & \\
\hline 3 & 107.4 & & 112.4 & \\
\hline 4 & 164.9 & & 169.0 & \\
\hline 5 & 53.1 & & 58.1 & \\
\hline 6 & 82.6 & & 80.1 & \\
\hline 7 & 79.8 & $4.62(\mathrm{dd}, 9.6,3.2)$ & 141.4 & $7.31(\mathrm{~d}, 15.6)$ \\
\hline 8 & 33.9 & $\begin{array}{l}2.53(\mathrm{dd}, 9.6,16.4) \\
2.85(\mathrm{dd}, 3.2,16.4)\end{array}$ & 124.3 & $6.39(\mathrm{~d}, 15.6)$ \\
\hline 9 & 170.5 & & 167.7 & \\
\hline 10 & 52.5 & $4.28(\mathrm{~s})$ & 55.1 & $4.56(\mathrm{~s})$ \\
\hline 11 & 57.9 & $3.54(\mathrm{~s})$ & 63.0 & $4.03(\mathrm{~s})$ \\
\hline 12 & 74.4 & $\begin{array}{l}4.29(\mathrm{~d}, 9.6) \\
4.12(\mathrm{~d}, 9.6)\end{array}$ & 62.6 & $\begin{array}{l}3.90(\mathrm{~d}, 11.4), \\
3.75(\mathrm{~d}, 11.4)\end{array}$ \\
\hline 13 & 51.6 & $3.65(\mathrm{~s})$ & 52.4 & $3.78(\mathrm{~s})$ \\
\hline $2^{\prime}$ & 163.3 & & 166.5 & \\
\hline $3^{\prime}$ & 110.0 & & 111.3 & \\
\hline $4^{\prime}$ & 168.1 & & 170.4 & \\
\hline $5^{\prime}$ & 116.3 & & 117.9 & \\
\hline $6^{\prime}$ & 156.3 & & 158.2 & \\
\hline $7^{\prime}$ & 40.8 & $4.26(\mathrm{~d}, 10.0)$ & 37.2 & $4.20(\mathrm{~d}, 11.4)$ \\
\hline $8^{\prime}$ & 47.2 & $3.92(\mathrm{~d}, 10.0)$ & 50.9 & $4.39(\mathrm{~d}, 11.4)$ \\
\hline $9^{\prime}$ & 169.2 & & 170.4 & \\
\hline $10^{\prime}$ & 52.8 & $4,35(\mathrm{~s})$ & 55.4 & $4.56(\mathrm{~s})$ \\
\hline $11^{\prime}$ & 62.1 & $4.08(\mathrm{~s})$ & 63.3 & $4.20(\mathrm{~s})$ \\
\hline $12^{\prime}$ & 52.2 & $\begin{array}{l}4.43(\mathrm{~d}, 12.4) \\
4.33(\mathrm{~d}, 12.4)\end{array}$ & 54.6 & $\begin{array}{l}4.55(\mathrm{~d}, 12.4), \\
4.46(\mathrm{~d}, 12.4)\end{array}$ \\
\hline $13^{\prime}$ & 51.7 & $3.67(\mathrm{~s})$ & 52.8 & $3.64(\mathrm{~s})$ \\
\hline
\end{tabular}

${ }^{a}$ Measured in DMSO- $d_{6}$ at $400 \mathrm{MHz}$ for ${ }^{1} \mathrm{H}$ and $100 \mathrm{MHz}$ for ${ }^{13} \mathrm{C}$.

1a $\left(5 R, 6 R, 7 R, 7^{\prime} S, 8^{\prime} S\right)$ and $\mathbf{1 b}\left(5 S^{*}, 6 S^{*}, 7 S^{*}, 7^{\prime} R^{*}, 8^{\prime} R^{*}\right)$ were unambiguously determined as shown in Fig. 1 .

$( \pm)$-Phomone B (2a/2b) shared the same molecular formula of $\mathrm{C}_{24} \mathrm{H}_{28} \mathrm{O}_{14}$ with compound 1 based on HRESIMS and ${ }^{13} \mathrm{C}$ NMR data. Detailed comparison of its NMR data (Table 1) with those of compound $\mathbf{1}$ indicated that the main differentiation between compounds 2 and 1 was the absence of the methene $\left[\delta_{\mathrm{H}} 2.53\right.$ $\left.(1 \mathrm{H}, \mathrm{dd}, J=16.4,9.6 \mathrm{~Hz}), \delta_{\mathrm{H}} 2.85(1 \mathrm{H}, \mathrm{dd}, J=16.4,3.2 \mathrm{~Hz})\right]$ and the methine $\left[\delta_{\mathrm{H}} 4.62(1 \mathrm{H}, \mathrm{dd}, J=9.6,3.2 \mathrm{~Hz})\right]$ and the presence of one trans-double bond signals $\left[\delta_{\mathrm{H}} 6.39(1 \mathrm{H}, \mathrm{d}, J=15.6 \mathrm{~Hz}), \delta_{\mathrm{H}}\right.$ $7.31(1 \mathrm{H}, \mathrm{d}, J=15.6 \mathrm{~Hz})]$ in compound 2 , which suggested that the furan ring might be open loop to the double bond additive and the C-12 primary alcohol. The HMBC spectrum (Fig. 2) corroborated the presence of a dihydropyrone ring from $\mathrm{H}_{2}-10$ $\left(\delta_{\mathrm{H}} 4.56\right)$ to $\mathrm{C}-2\left(\delta_{\mathrm{C}} 166.5\right), \mathrm{C}-3\left(\delta_{\mathrm{C}} 112.4\right)$ and $\mathrm{C}-4\left(\delta_{\mathrm{C}} 169.0\right)$ and from $\mathrm{H}_{2}-12\left(\delta_{\mathrm{H}} 3.75 / 3.90\right)$ to C-4, C-5 $\left(\delta_{\mathrm{C}} 58.1\right)$ and C-6 $\left(\delta_{\mathrm{C}} 80.1\right)$ and an $\alpha$-pyrone moiety based on correlations from $\mathrm{H}_{2}-10^{\prime}\left(\delta_{\mathrm{H}}\right.$ 4.56) to $\mathrm{C}-2^{\prime}\left(\delta_{\mathrm{C}} 166.5\right), \mathrm{C}-3^{\prime}\left(\delta_{\mathrm{C}} 111.3\right)$ and $\mathrm{C}-4^{\prime}\left(\delta_{\mathrm{C}} 171.4\right)$ and from $\mathrm{H}_{2}-12^{\prime}\left(\delta_{\mathrm{H}} 4.55 / 4.46\right)$ to $\mathrm{C}-4^{\prime}, \mathrm{C}-5^{\prime}\left(\delta_{\mathrm{C}} 117.9\right)$ and $\mathrm{C}-6^{\prime}\left(\delta_{\mathrm{C}}\right.$ 158.2). Further HMBC correlations observed from $\mathrm{H}-7^{\prime}\left(\delta_{\mathrm{H}} 4.20\right)$ to $\mathrm{C}-5$ and $\mathrm{C}-8^{\prime}\left(\delta_{\mathrm{C}} 50.9\right)$ and from $\mathrm{H}-8^{\prime}\left(\delta_{\mathrm{H}} 4.39\right)$ to $\mathrm{C}-7^{\prime}\left(\delta_{\mathrm{C}} 37.2\right)$, C-9' $\left(\delta_{\mathrm{C}} 170.4\right)$, C-6 and C-7 $\left(\delta_{\mathrm{C}} 141.4\right)$ demonstrated two $\alpha$-pyrone rings should be conjugated through a cyclobutane ring and the additional $\alpha, \beta$-unsaturated ester moiety was obviously attached to C-6 due to the confirmation of the HMBC correlations from $\mathrm{H}$ -
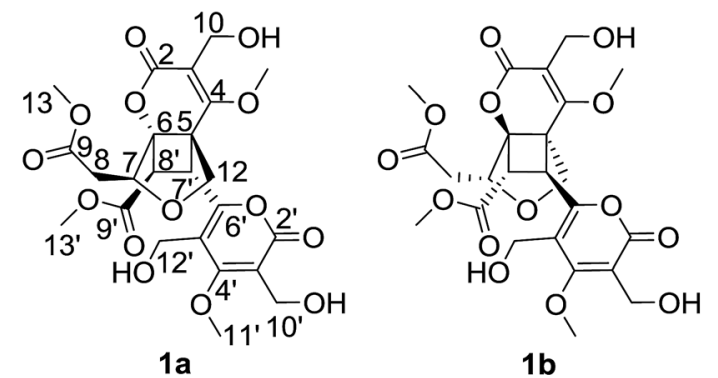

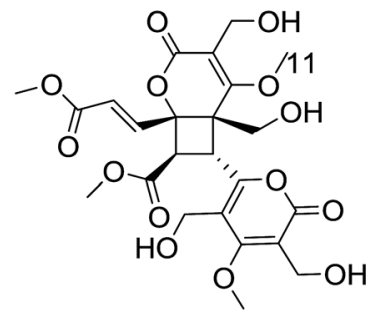

$2 a$

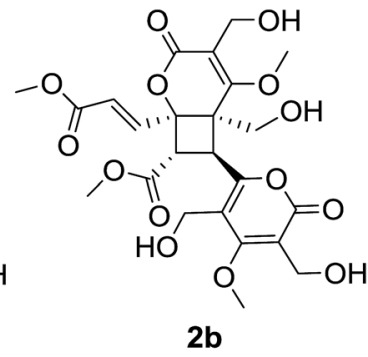

2b<smiles>COC(=O)/C=C/c1oc(=O)c(CO)c(OC)c1CO</smiles>

Fig. 1 Structures of compounds 1-3.

$7\left(\delta_{\mathrm{H}} 7.31\right)$ to $\mathrm{C}-6$ and C-8 $\left(\delta_{\mathrm{C}} 124.3\right)$, and C-9 $\left(\delta_{\mathrm{C}} 167.7\right)$ established the planar structure of compound 2 as shown in Fig. 1.

The NOESY spectrum gave diagnostic correlations of $\mathrm{H}-7^{\prime}$ with $\mathrm{H}_{2}-12$ and $\mathrm{H}-7^{\prime}$ with $\mathrm{H}-7$, which illustrated $\mathrm{H}-\mathrm{7}^{\prime}, \mathrm{H}_{2}-12, \mathrm{H}-7$ oriented in the same direction, and analyses of the coupling constants placed $\mathrm{H}-\mathrm{8}^{\prime}$ on the opposite side of the cyclobutane ring. Subsequent chiral resolution of compound 2 was performed on a chiral column to yield $2 \mathbf{a}$ and $2 \mathbf{b}$ in a ratio of $1: 1$, which were virtually opposite in terms of their CD curves (Fig. 5). The final assignment of $2 \mathbf{a}\left(5 S, 6 S, 7^{\prime} R, 8^{\prime} R\right)$ and $2 \mathbf{b}(5 R$, $6 R, 7^{\prime} S, 8^{\prime} S$ ) was made by the comparison of the calculated electronic circular dichroisms (ECD) via a quantum method with the experimental data (Fig. 5).

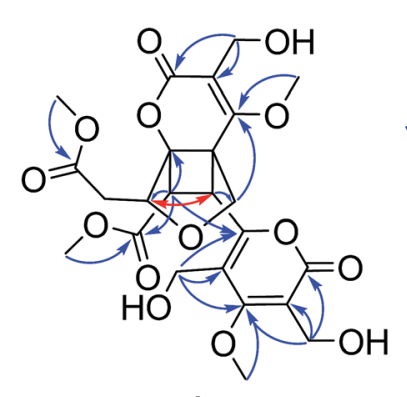

1

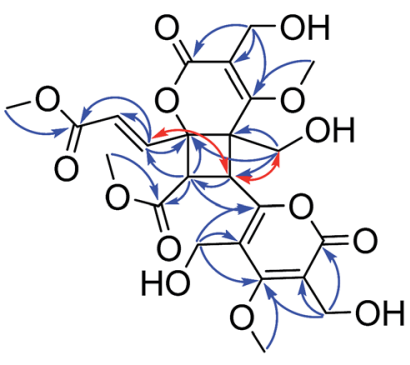

2

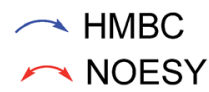

Fig. 2 Key HMBC and Noesy correlations of compounds 1 and 2. 


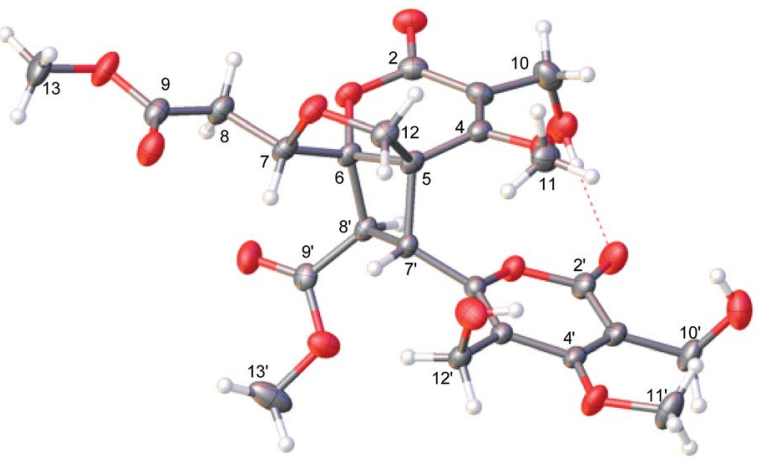

Fig. 3 X-ray crystallographic data for 2.

It was found that compound 2 slowly transformed to compound 1 in $\mathrm{MeOH}$ over one month, which indicated that a cyclization reaction was occurring. The effect of $\mathrm{H}_{2} \mathrm{O}-, \mathrm{pH}$ - and temperature-dependent transformation between phomones $\mathrm{A}$ (1) and B (2) were further studied. As shown in Fig. S21, $\dagger$ the $\mathrm{H}_{2} \mathrm{O}$-temperature heating experiment suggested that $\mathrm{H}_{2} \mathrm{O}$ could promote transformation and the epimerization was quite sensitive to $\mathrm{H}_{2} \mathrm{O}$. The $\mathrm{pH}$-dependent experiment revealed that the transformation was smothered by acid (Fig. S24†) and promoted by alkali (Fig. S22†). Meanwhile, it was not going to make the alkali promote retransformation successful (Fig. S23 $\dagger$ ). The variable-temperature heating experiment (Fig. S25†) revealed that the single compound 2 was stable in anhydrous ethanol solution below $50{ }^{\circ} \mathrm{C}$ for 12 hours. Based on the above results, epimerization of 2 and 1 could be induced by $\mathrm{H}_{2} \mathrm{O}$ and alkali. The main effect of these transformed observations was $\mathrm{H}_{2} \mathrm{O}$, since $\mathrm{H}_{2} \mathrm{O}$ might come into being along with the fermentation. In our study, three pairs of enantiomers, $( \pm)$ phomones A (1), B (2) and the acetylated products $\mathbf{4 a} / \mathbf{4 b}$ (Scheme 2) were successfully separated by HPLC employing a CHIRALPAK AD-H chiral column $(250 \times 4.6 \mathrm{~mm}, 5 \mu \mathrm{m})$ and using anhydrous ethanol as the mobile phase at a flow rate of $0.3 \mathrm{~mL} \mathrm{~min}^{-1}$.

As phomone A (1) and B (2) are 6- $\alpha, \beta$-unsaturated ester-2pyrone dimers, a close biosynthetic relationship could be

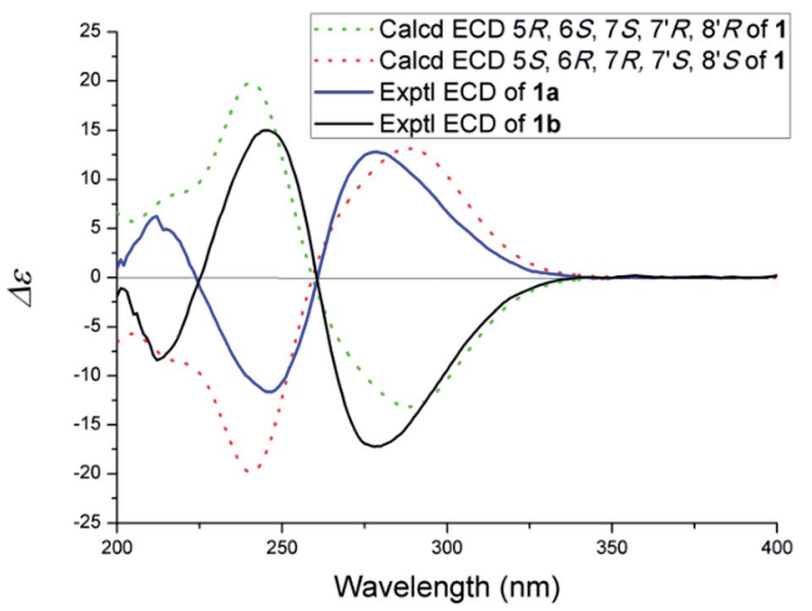

Fig. 4 Experimental and calculated ECD spectra of 1.

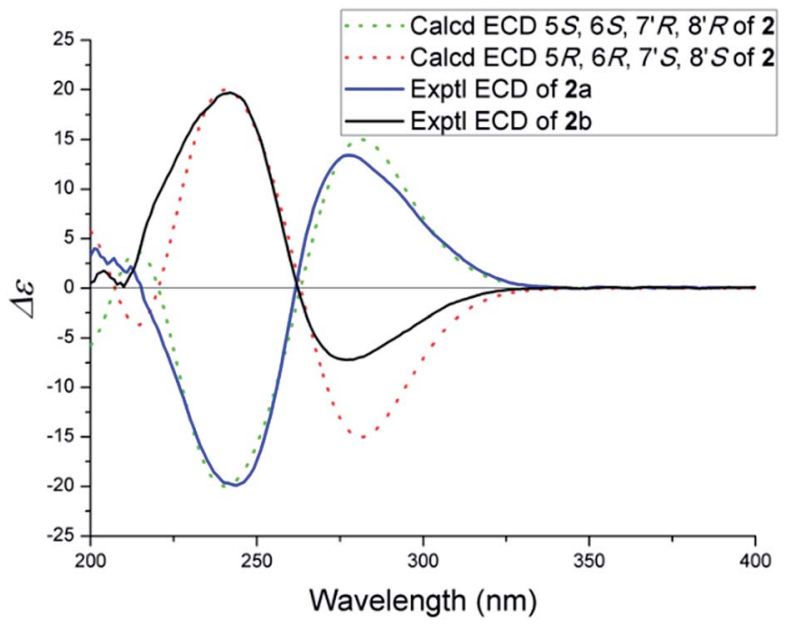

Fig. 5 Experimental and calculated ECD spectra of 2.

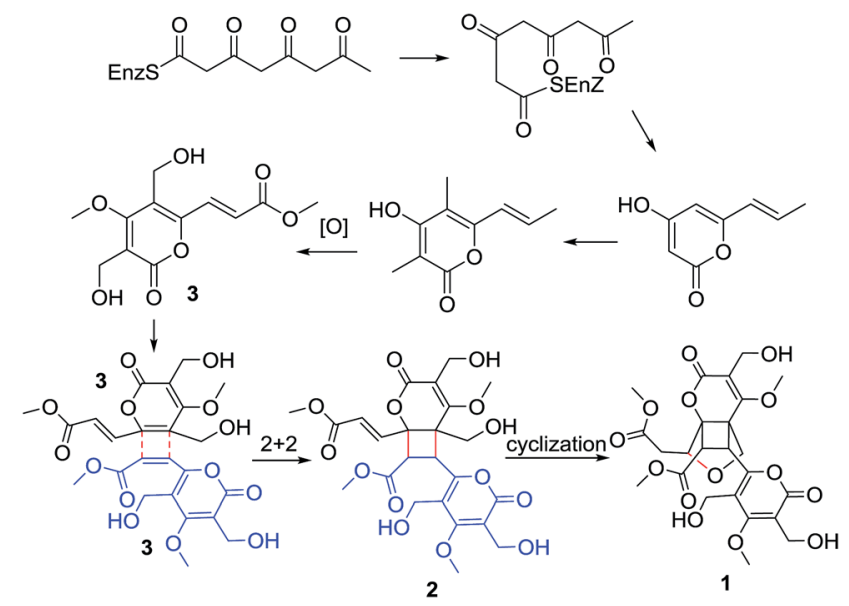

Scheme 1 Suggested biosynthetic pathway of 1 and 2 .

1

$\downarrow \begin{aligned} & \text { Acetic Anhydride } \\ & 12 \mathrm{~h}, \mathrm{rt}\end{aligned}$

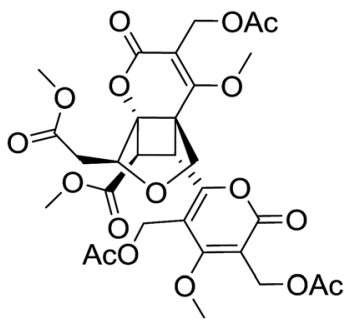

$4 a$

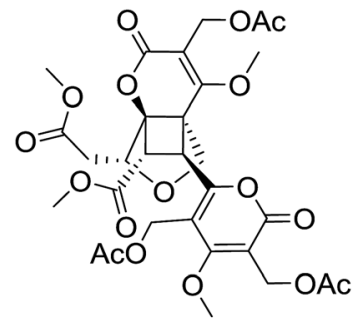

4b
Scheme 2 Acetylated of phomone A (1).

speculated. Phomone B (2) may be derived through a intermolecular unsymmetrical $[2+2]$ cycloaddition reaction of two ethylenic bonds between two rosellsin (3) molecules phomone A (1) could be formed through an intramolecular cyclization reaction of phomone $\mathrm{B}(2)$ (Scheme 1). 
Compounds 1 and 2 showed no activity $\left(\mathrm{IC}_{50}>50 \mu \mathrm{M}\right)$ when evaluated for their cytotoxic activity against three human cancer cell lines, including human leukemia HL-60, human prostatic carcinoma PC-3 and human colon cancer HCT-116, using 5 -fluorouracil as positive control. The acetylated products $(\mathbf{4 a} /$ 4b) of compound 1 showed moderate cytotoxic activity against HL-60 cell line with $\mathrm{IC}_{50}$ value of $11.05 \mu \mathrm{M}$ and $14.18 \mu \mathrm{M}$, respectively.

\section{Acknowledgements}

This work was supported by National Natural Science Foundation of China (No. 81502951).

\section{Notes and references}

1 H. I. Omar, T. Shimo and K. Somekawa, J. Mol. Struct.: THEOCHEM, 2006, 763, 115-121.

2 Y. Yanagisawa, Y. Nishiyama, H. Tanimoto, T. Morimoto and

K. Kakiuchi, Tetrahedron Lett., 2014, 55, 2123-2126.

3 A. Furutani, K. Tsutsumi, H. Nakano, T. Morimoto and K. Kakiuchi, Tetrahedron Lett., 2004, 45, 7621-7624.

4 M. Zhou, X. R. Li, J. W. Tang, Y. Liu, X. N. Li, B. Wu, H. B. Qin, X. Du, L. M. Li, W. G. Wang, J. X. Pu and H. D. Sun, Org. Lett., 2015, 17, 6062-6065.

5 C. S. Yang, X. B. Wang, J. S. Wang, J. G. Luo, J. Luo and L. Y. Kong, Org. Lett., 2011, 13, 3380-3383.
6 T. Sunazuka and S. Omura, Chem. Rev., 2005, 105, 45594580.

7 H. I. Omar, Y. Odo, Y. Shigemitsu, T. Shimo and K. Somekawa, Tetrahedron, 2003, 59, 8099-8105.

8 T. Obata, T. Shimo, M. Yasutake, T. Shinmyozu, M. Kawaminami, R. Yoshida and K. Somekawa, Tetrahedron, 2001, 57, 1531-1541.

9 Y. Li, D. Z. Ye, X. L. Chen, X. H. Lu, Z. Z. Shao, H. Zhang and Y. S. Che, J. Nat. Prod., 2009, 72, 912-916.

10 T. Suishu, T. Shimo and K. Somekawa, Tetrahedron, 1997, 53, 3545-3556.

11 T. Shimo, M. Matsushita, H. I. Omar and K. Somekawa, Tetrahedron, 2005, 61, 8059-8064.

12 T. Shimo, S. Ueda, T. Suishu and K. Somekawa, J. Heterocycl. Chem., 1995, 32, 727-730.

13 X. N. Sang, S. F. Chen, G. Chen, X. An, S. G. Li, X. N. Li, B. Lin, J. Bai, H. F. Wang and Y. H. Pei, $R S C A d v .$, 2016, 6, 6489064894.

14 X. N. Sang, S. F. Chen, X. An, G. Chen, H. F. Wang and Y. H. Pei, J. Asian Nat. Prod. Res., 2016, 7, 1-8.

15 M. S. R. Nair and S. T. Carey, Tetrahedron Lett., 1975, 41, 3517-3518.

16 T. Sagawa, Y. Takaishi, Y. Fujimoto, C. Duque, C. Osorio, F. Ramos, C. Garzon, M. Sato, M. Okamoto, T. Oshikawa and S. U. Ahmed, J. Nat. Prod., 2005, 68, 502-505.

17 I. Ortmann, S. Werner, C. Kruger, S. Mohr and K. Schaffner, J. Am. Chem. Soc., 1992, 114, 5048-5054. 